\title{
EMOTIVE SPEECH ACTS \\ AND THEIR DISCOURSE MODIFICATIONS \\ IN THE LITERARY TEXT
}

\author{
Svitlana Zhabotynska and Nataliia Slyvka
}

\begin{abstract}
This article focuses on three related theoretical problems: classification of expressive speech acts that till present remains a highly disputable issue of linguistic pragmatics, specificity of emotives as a type of expressives, and the patterns of emotives' modifications in the current discourse space as it is represented in the literary text. The authors suggest a classification of expressive speech acts built at the intersection of the cognitive (semantic), communicative and semiotic planes that demonstrate distinctions between the classes of behavitives and emotives and between their sub-classes. It is further presumed that emotives, when used in discourse, get modified in accordance with regular patterns compatible with the cognitive operations of elaboration, extension, questioning, and combining described in different cognitive linguistic conceptions. This presumption is confirmed via analysis of positive emotives portrayed in the literary text which, besides the character's speech proper, describes the other discourse aspects relevant for the illocutionary meaning of a speech act. The patterns of discourse modifications exhibited by positive emotives as a congeneric sub-class are considered to be relevant for the other sub-classes of emotives - negative, bi-polar and ambivalent.
\end{abstract}

\section{Keywords}

expressive speech acts, classification, emotives, positive emotives, modifications, current discourse space, elaboration, extension, questioning, combining

\section{Introduction}

The initial pivot of contemporary communicative linguistics is the speech act theory introduced by Austin (1962), who distinguished between constative and performative language. Constative language, or 'locution', refers to things and reports on reality with truth condition in view. Performative language, or 'illocution', is the speaker's communicative intention underpinning locution and targeting the listener. Performative language realized through speech acts is that which "does things" - it is speech in action (Oventile 2005: 1016-1017). The illocution types provide a basis for speech act taxonomies which remain a matter of ongoing linguistic debate. The first taxonomy was suggested by Searle (1969), who proposed five types of speech acts - assertives, directives, commissives, expressives, and declarations. In numerous successive works 
Searle's classes have been specified and extended, as well as criticized with an attempt to develop an improved typology (see, for instance, Vernant 2008). However, Searle's classes per se have never been renounced. Of late, they have become foundational for "a cognitive typology of speech acts" (Dirven \& Verspoor 2004: 154-155) that provides thematic grouping of speech act types into three categories: (1) INFORMATIVE SPEECH ACTS - assertives (which render information) and information questions (which enquire for information), (2) OBLIGATIVE SPEECH ACTS - directives (which impose obligation on the listener) and commissives (which impose obligation on the speaker), and (3) CONSTITUTIVE SPEECH ACTS - declaratives (which constitute physical reality, such as name giving or declaration of war), and expressives (which constitute psychological reality through apology, congratulations, thanks, etc.).

In the above classification, the most diverse and controversial are constitutives, expressives in particular. Rendered by "a myriad of unconnected speech acts" (Maíz-Arévalo 2017: 6), in contrast to other types of speech acts, the category of expressives "has traditionally proven elusive of definition" (ibid.: 151). Represented by numerous sub-types associated with 'positive' and 'negative' emotions, expressives function in established social contexts and in variable conversational settings. Conversational expressives that communicate the speaker's emotions are termed 'emotives' (Weigand 2010). In contemporary pragmatic studies, the properties of emotives are open to further investigation both semantically and functionally, i.e. in their relation with the context. This paper aims to specify the illocutionary content of emotives, outline their thematic stratification, and expose the patterns of their modifications in the current discourse space shown in the literary text where the author features both the characters' communication and its attendant extralinguistic context. The patterns of emotives' modifications are established via analysis of positive emotives as an illocutionary homogeneous group whose properties may be attributed to the other types of emotives.

The further enquiry has four sections. Section 2 provides definition of emotives and suggests their classification grounded on the previous findings and our own considerations. Section 3 represents the data of this study and describes the methodology for identifying the patterns of modifications demonstrated by emotives as they are portrayed in literary texts. Section 4 demonstrates application of this methodology to the analysis of empirical data, and discusses the obtained results. Section 5 draws the conclusions and ponders on the implications of this research. 


\section{Emotives as a sub-type of expressive speech acts}

Ambiguity of expressive speech acts can be traced back to the classical works. Austin (1962) distinguishes 'behavitives' as the acts having to do with social behavior and attitudes. Searle (1969), who calls such acts 'expressive', maintains that their illocution represents the speaker's psychological reaction to the state of affairs specified in the propositional content. Searle exemplifies expressives with apologizing, congratulating and thanking. However, studies of empirical data expose the necessity to increase the scope of expressives, since many speech acts that intuitively belong to expressives do not fit into any of Searle's types (Carretero et al. 2015: 187). According to Norrick (1978: 279), "[e]xpressives are distinguished from other kinds of illocutionary acts by virtue of the types of psychological condition - they express. Expressives do not express beliefs or intentions, but emotions" which "arise in response to given states of affairs". Norrick's subdivision of expressive speech acts grounds on the taxonomy of interacting emotions and includes: apologizing, thanking, congratulating, condoling, deploring, lamenting, welcoming, forgiving, and some instances of boasting (ibid.: 279). The recent enquiries concerned with classifying expressives (Ronan 2015, Lalu \& Yuyun 2017, Alekseev \& Shipilova 2018 among others) add some new groups.

As Maíz-Arévalo (2017: 154) correctly observes, many of the suggested taxonomies do not differentiate between socially-expected and more self-centered expressives, or between social and basic emotions reported by LewandowskaTomaszczyk and Wilson (2014). Social emotions involve an interactant, while basic emotions, such as fear, surprise or disgust, do not necessarily assume the presence of an interlocutor, although the degree of their socialization function does not need to be identical (Lewandowska-Tomaszczyk \& Wilson 2014: 125). Socially expected acts tend towards a higher degree of formulaicity which, however, remains fluctuant (Maíz-Arévalo 2017: 154). The distinction between socially-centered and self-centered expressives is drawn by Weigand (2010). She treats socially-expected conventionalized expressives (such as congratulations, condolences, thanks or excuses) as declaratives that do not express sincere feelings and just serve to create social rapport in routines of behavior (ibid.: 179), and she defines self-centered expressives as emotives that demonstrate the speaker's emotional involvement, or emotional affect (ibid.: 166). Whilst declaratives are relatively formulaic and lexically bleached as a polite mitigator of the request to avoid face-threatening the interlocutor, emotives retain their original 'emotional' meaning aimed at evoking the hearer's feedback. Maíz-Arévalo (2017), who draws attention to this fact, specifies it as follows: 
Emotives, in contrast to other speech acts like declaratives, are not only truthconditioned, but link that truth to the interlocutors' emotional side, to their feelings and opinions, expecting back empathy and/or compassion. Thus, emotives may not be specifically demanded by the social situation per se but, when/if they happen, they can lead to social rapport among the interactants. In other words, when the speaker 'opens up' to the hearer, she might also be implicitly acknowledging that their degree of closeness has become suitable enough to do so and hence invite reciprocity on the hearer's part so as to increase their rapport by entering each other's private sphere (ibid.: 157).

Unlike Weigand (2010), Carretero et al. (2015: 187) do not define socially-centered expressives as declaratives. The authors suggest a corpusdriven taxonomy including expressives of two general types: self-centered, pertaining to the speaker/writer's feelings, and other-centered, focused on the addressee's feelings. Self-centered expressives include: likings (which express positive emotional reactions), concerns (which express worries), and wishes (which claim that the truth of the proposition should or should not be the case). Other-centered expressives include apologies, compliments and thanks that correspond to Searle's expressives, as well as other subtypes: reassurings (which aim at comforting the addressee by diminishing his/her feeling of guilt), and reproaches (which may be seen as the negative counterpart of compliments). In other studies (e.g. Guiraud et al. 2011), expressives are qualified as a particular kind of assertive speech acts where the propositional content is about a psychological state.

A psychological state of the speaker makes the common foundation for all kinds of expressives, irrespective of the names they obtain. The attempts to describe this foundation involve classifications of emotions. For example, Maíz-Arévalo (2017) adopts Weigand's (2010) stratification of expressives into declaratives and emotives, and associates them with Guiraud et al.'s (2011) division of emotions into basic and complex. Basic emotions are defined only from beliefs and goals. Complex emotions are based on complex reasoning about norms, responsibility, etc. (ibid.: 6). In Maíz-Arévalo's (2017: 12) taxonomy, positive basic emotions are joy and approval; positive complex emotions include rejoicing, admiring, moral satisfaction and gratitude; negative basic emotions are represented by sadness and disapproval; negative complex emotions comprise guilt, regret, disappointment and reproach. The studies of expressive speech acts done in Ukraine and Russia (Orlova 2008, Velivchenko 2011, Slyvka 2012, Kisil 2018 as instances) tend to give preference to Izard's $(1977,1991)$ theory 
of differential emotions that emphasizes ten distinct and discriminable basic patterns: joy, interest-excitement, surprise, anguish, rage, revulsion, scorn, fear, shame, and guilt. Among them, are positive (joy, interest-excitement), negative (anguish, rage, revulsion, scorn, fear, shame, and guilt), and neutral (surprise) emotional states. Neutral emotions (Lomas 2017), such as hope, longing, pathos, etc. may be ambivalent - both positive and negative.

In general, dovetailing psychological taxonomies of emotions with a linguistic typology of expressive speech acts is a problem triggered by their unwarranted one-to-one match.

The first complication is caused by vagueness of emotions and feelings as a research object which is difficult to precisely define. In this study, we adopt Damasio's (1999: 55-56) understanding of EMOTIONS as "complex, stereotyped patterns of response" to BASIC LIFE REGULATIONS of the biological machinery and culture. Emotions, in their turn, may trigger FEELINGS as sensory image patterns. In this interpretation, emotions and (emotive) feelings are contiguous. Further, Damasio argues:

The classes of stimuli that cause happiness or fear or sadness tend to do so fairly consistently in the same individual and in individuals who share the same social and cultural background. In spite of all the possible individual variations in the expression of emotion and in spite of the fact that we can have mixed emotions, there is a rough correspondence between classes of emotion inducers and the resulting emotional state. Throughout evolution, organisms have acquired the means to respond to certain stimuli - particularly those that are potentially useful or potentially dangerous from the point of view of survival - with the collection of responses which we currently call an emotion (ibid.: 56-57).

Supposedly, the responses to 'useful' and 'dangerous' stimuli incur the initial evaluation GOOD and BAD coupled with the respective 'positive' and 'negative' emotions.

The second complication is diversity of psychological taxonomies of emotions, which is accounted for by indistinct demarcation lines in between different psychological states (see the considerations in Ortony \& Turner 1990, Zachar 2006, Lewis et al. 2008 among others). As Thamm (2006) notes, 
From various traditions, philosophers have postulated a set number of salient human emotions. Aristotle maintained that there were 15 basic emotions, Descartes listed six, Hume listed only two, Spinoza mentioned three, Hobbes mentioned seven, Aquinas had eleven, and Nietzsche, Darwin, and others proposed various numbers for basic emotions. $<\ldots>$ Until the present, scholars have not been able to specify the differences among a wide range of emotion categories in any systematic way. For example, they have not been able to successfully differentiate specific meanings for common emotion labels such as guilt, regret, embarrassment, and shame. It is also probable that for this reason, they have failed to reach agreement on which emotions are elemental and which are not (ibid.: 11-12).

It is plausible to presume that a linguistic typology of expressives should be flexible enough to accommodate various types of emotions identified by psychologists. We propose to develop such a typology at the intersection of cognitive (semantic), communicative and semiotic planes (Figure 1).

The cognitive (semantic) plane of expressives pertains to the GOOD and BAD assessments build into emotions. GOOD entails LIKING that causes SATISFACTION triggering PLEASURE. BAD entails DISLIKING that causes DISSATISFACTION accompanied by DISPLEASURE. This assumption is in accord with psychologists' observations on our ability to experience several emotions simultaneously (see Guiraud 2011: 1037). Psychologically, the consecutive chain GOOD $\rightarrow$ LIKING $>$ SATISFACTION $>$ PLEASURE, as well as the similar chain BAD $\rightarrow$ DISLIKING $>$ DISSATISFACTION > DISPLEASURE is an integrity, or 'blend'. Its 'de-blending' and atomization of the constituents means not their separation, but their forefronting and prominence. For example, LIKING means that this element is most salient, with SATISFACTION and PLEASURE backgrounded and implied. 


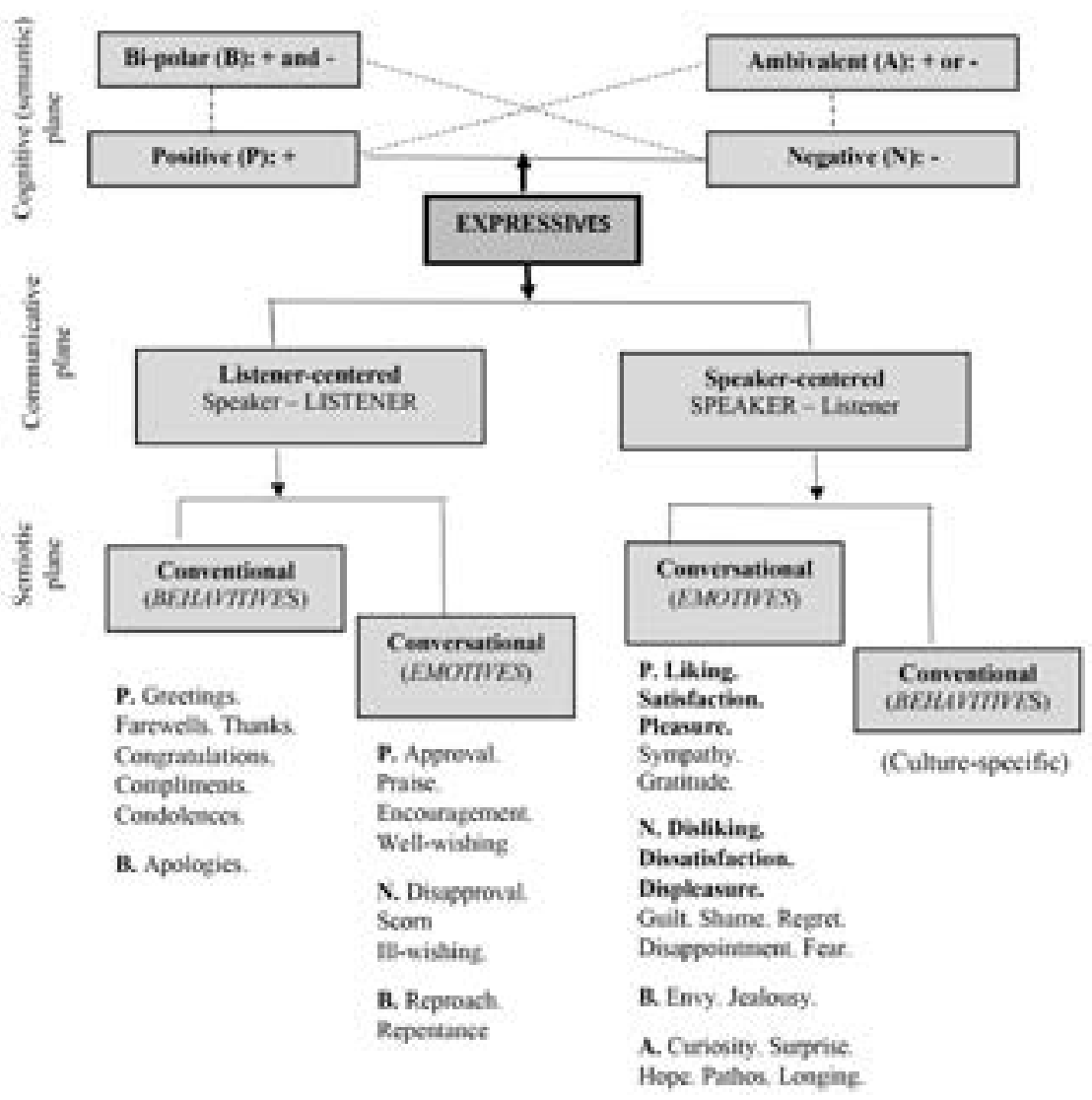

Figure 1. Classification of expressive speech acts

In the groups of positive, negative, bi-polar and ambivalent emotions communicated by the speaker, the assessments GOOD and BAD are represented in a particular way.

(a) Positive emotions (P) may be elementary and non-elementary. Elementary positive emotions - LIKING, SATISFACTION and PLEASURE do not disintegrate into constituents. LIKING may have such variations as 'attraction', 'love', 'admiration', 'worship', etc. SATISFACTION is cognate with 'gladness'. PLEASURE is exposed in 'happiness' 'joy', 'rejoicing', etc. Non-elementary positive emotions, besides an elementary positive emotion (or emotions), include other constituents concerned with the 
speaker's positive psychological state. Non-elementary positive emotions are: 'sympathy' (liking + pity), 'gratitude' (liking + appreciation), 'approval' (liking + appropriateness), 'praise' (liking + value), 'encouragement' (liking + concern), 'well-wishing' (liking + wishing somebody something good), etc.

(b) Negative emotions $(\mathrm{N})$ may be also elementary and non-elementary.Elementary negative emotions - DISLIKING, DISSATISFACTION and DISPLEASURE do not disintegrate into constituents. DISLIKING is varied in 'hate', 'loath', 'aversion', 'disgust', 'revulsion', etc. Variations of DISSATISFACTION are 'anger', 'wrath', 'rage', etc. DISPLEASURE is manifested in 'sadness', 'grief' 'mourning', 'anguish', etc. Non-elementary negative emotions, besides an elementary negative emotion (or emotions) have other constituents concerned with the speaker's negative psychological state. Non-elementary negative emotions are represented by 'guilt' (disliking + displeasure + remorse), 'shame' (disliking + displeasure + social reprobation), 'regret' (disliking + displeasure + repentance), 'disappointment' (disliking + dissatisfaction + false hopes), 'fear' (disliking + displeasure + apprehension), 'disapproval' (disliking + inappropriateness), 'scorn' (disliking + low value), 'ill-wishing' (disliking + wishing somebody something bad), etc.

(c) Bi-polar emotions (B) merge the speaker's positive (negative) evaluation of oneself, and negative (positive) evaluation of the other entity. Bi-polar emotions are non-elementary. For example, 'envy' (liking something + disliking not having it in self's possession), 'jealousy' (liking somebody + disliking the other's attraction to him/her), 'reproach' (disliking the other's inappropriate deed + liking the self-suggested appropriate deed), 'repentance' (self-disliking, recognizing the other's righteousness), etc.

(d) Ambivalent emotions (A), being neutral, or initially devoid of positive or negative assessments, may obtain it in the context and become the respective non-elementary emotions. These are 'curiosity', 'surprise', 'hope', etc.

Similar to elementary emotions, non-elementary ones may also vary within one type, which is displayed by the groups of synonyms, such as 'praise', 'laud', 'glorification', 'eulogizing', and others.

The lists of emotions in the above taxonomy may be elaborated and extended via application of componential analysis to illocutionary meanings (Zhabotynska 2018 may serve as an instance), which gets beyond the scope of this linguistic enquiry. The data for such analysis may come from both linguistic and psychological sources, especially the ones aimed at discovering the 'anatomy' of emotions through their empirical studies (Lindquist 2013, Aristidou et al. 2015 among others). 
The communicative plane of expressives divides them into listener-centered and speaker-centered. Listener-centered expressives are addressed to the listener; speaker-centered expressives just communicate the speaker's emotion and do not imply the listener's compulsory involvement.

In the semiotic plane, expressives may be split into conventional, rendered by relatively canonical linguistic forms, and conversational, whose forms are not restricted to particular linguistic patterns. In consonance with Austin (1962), conventional listener-centered expressives may be termed behavitives. Conversational expressives - self-centered and listener-centered - are emotives. Emotives and behavitives tend to form semantic doublets and triplets, such as 'gratitude - thanks', 'guilt - apologies', 'liking - praise - compliments', or 'sympathy - encouragement - condolences'. It can be argued that the boundary between conventional and conversational expressives, or behavitives and emotives, is established by social convention: expression of a particular emotion (either listener-centered or speaker-centered) may be formulaic in one culture, and pattern-free in another culture (cf. Wierzbicka 1997).

The suggested classification of expressives delineates the boundaries of the studied phenomenon. On the one hand, this phenomenon - the pragmatic category of emotives - is distinguished from the category of behavitives. On the other hand, emotives proper split into listener-centered and speaker-centered - the types subsuming a number of sub-types defined as positive, negative, bi-polar and ambivalent emotives. Their particularization (see Figure 1) guides selection of the linguistic data, the properties of which are to be studied. In this enquiry, such properties are primarily concerned with the patterns of modifying the illocutionary content of emotives used in discourse as it is presented in the literary text. These patterns are exemplified with discourse modifications of positive emotives.

\section{Data and methodology}

The data are obtained from 14 novels (over 6,000 pages) by the contemporary American writer Danielle Steel renowned for her contribution to the 'love-story' genre. The choice of this genre is accounted for by the expected abundance of positive emotives (PE) in the literary text. The dataset $-2,286$ of contexts including a positive emotive/emotives - was obtained by the method of continuous sampling. PE were identified through their illocutionary meanings - listener-centered (approval, praise, encouragement, and well-wishing) and speaker-centered (liking, satisfaction, pleasure, sympathy, and gratitude) rendered verbally and non-verbally in the characters' communication described 
in the text. An additional diagnostic device was the author's description of the characters' psychological states.

Our guiding hypothesis is that an emotive speech act interacts with the current discourse space, where it gets modified. The term current discourse space was introduced by Langacker (2008), who defines it as follows:

As discourse unfolds, at each step the current expression is constructed and interpreted against the background of those that have gone before. The prior discourse is a major determinant (along with context, background knowledge, etc.) of what I call the current discourse space (CDS). The CDS is a mental space comprising everything presumed to be shared by the speaker and hearer as the basis for discourse at a given moment. Starting from the basis, each successive utterance updates the CDS in some fashion (ibid.: 59).

Langacker's definition of the current discourse space agrees with van Dijk's (1981) description of discourse as a communicative event in which the speakers' interaction is mediated by a text. This definition also resonates with Arutyunova's (1990: 136) interpretation of discourse as "speech immersed into life", or as a coherent text taken together with its extralinguistic - pragmatic, socio-cultural, psychological, etc. - factors. Understanding of discourse as a complex phenomenon constituted by overt verbal and non-verbal manifestations of the speakers' cognition, with these manifestations being linked to the speakers' covert thoughts and emotions, legitimizes application of the literary text as a source of data for discourse studies, an enquiry of emotives in particular. In the literary text, emotive speech acts used in the interaction of characters are portrayed with regard to a number of discourse constituents. These are: (a) the character's speech with its explicit or implicit illocution, (b) the non-verbal means that accompany this speech and contribute to its illocutionary meanings, and (c) the character's mental state underlying his/her speech. Besides, while portraying an emotive speech act of the character, (d) the author may provide a personal interpretation of this speech act. All such constituents may be considered as discourse (communicative) media instantiating an emotive speech act and contributing to modifications of its pragmatic content.

In our study, instantiations of an emotive speech act in the character's speech proper are considered to be primary [Instantation ${ }^{1}$; instantiations of an emotive speech act in the non-verbal means and in the character's externalized mental states attending this speech are viewed as secondary [Instantiation ${ }^{2}$; and instantiations of an emotive speech act in the character's covert mental states to which the narrator has an access as a virtual 'observer' are defined as tertiary 
[Instantiation $\left.{ }^{3}\right]$. While primary and secondary instantiations of an emotive are inherent in the communicative situation described in the literary text, the tertiary instantiations are a distinctive feature of the literary text per se which, as van Dijk (1976) notes, provides interaction of the writer and reader. While portraying an emotive speech act, the author makes the character's speech 'perceptible' for the reader in all aspects that may be overt and covert for the listener in the described communicative event.

It is further hypothesized that primary, secondary and tertiary instantiations of an emotive speech act are engaged in molding the illocutionary content of this act. In the current discourse space, such content is modified in accordance with regular patterns. Their exposure can be informed by linguistic conceptions focusing on the cognitive operations of extending/extension, elaboration, questioning and combining.

Extending, elaboration, questioning and combining were first described by Lakoff and Turner (1989) as the devices for developing poetic metaphors out of ordinary conceptual (conventional) metaphors. Extending a conventional conceptual metaphor adds new elements to it. Elaboration employs an existing element in an unusual way. In questioning, poets call into question the boundaries of our everyday understanding of important concepts. Combining, or composing, is going beyond the conventional metaphoric thought via formation of composite metaphors (ibid.: 67-70). The above devices look like the ones that outreach the scope of metaphoric creativity and get traction in other linguistic phenomena. It is demonstrated, in particular, by the broader meanings assigned to the terms 'elaboration' and 'extension' in Langacker's (2008) cognitive grammar. By elaboration Langacker understands specification of the concept via adding the new details. For example, rodent $\rightarrow$ rat $\rightarrow$ large brown rat $\rightarrow$ large brown rat with halitosis. In elaboration, the schematic and specific meanings remain coreferent (ibid.: 56). Similar interpretation of the term exists in the theory of conceptual integration, where elaboration is regarded as 'pattern completion' (Fauconnier \& Turner 2002: 48-49). By extension, Langacker (2008: 250) means associative interaction of not co-referent concepts that are linked through contiguity (metonymically) or likeness (metaphorically).

In our research, 'elaboration', 'extension', 'questioning' and 'combining' are understood as discourse devices for modification of a PE, and interpreted as follows: (a) elaboration - the current discourse space provides details about a particular positive emotion proper; (b) extension - the current discourse space supplies additional information fitting the 'frame' of attendant circumstances congruent with a particular positive emotion (for instance, the information as to its cause or consequence); (d) questioning - the current discourse space supplies 
additional information that contradicts attendant circumstances congruent with a particular positive emotion; questioning is a version of extension concerned with 'incongruent' information; (c) combining - in the current discourse space a PE of one type combines with a PE of another type; or a PE of one and the same type is attributed to different related referents. These discourse devices are interdependent: they constitute a structural unity that is used to describe a prominent textual referent associated with a particular PE, and thus contributes to the relational coherence of a text (Figure 2).

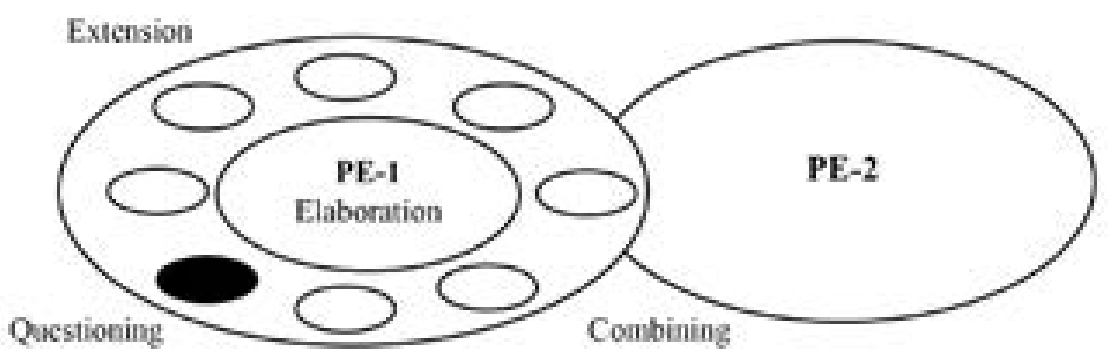

Figure 2: Correlation of elaboration, extension, questioning and combining

Therefore, in the current discourse space, a PE may undergo modifications: it is specified via elaboration; it is supplied with information about congruent and incongruent attendant circumstances due to extension and questioning respectively; it allies with a contiguous $\mathrm{PE}$ through combining. The modifications of a PE may be considered in terms of 'nucleus - satellite' hypotactic coherence relations described by Mann and Thompson (1988). In this case, the pragmatic meaning of a PE is the 'nucleus', and its modification is a subordinate 'satellite'. This argument puts on flesh in the further analysis which, besides the patterns of modification exhibited by PE in discourse, highlights the issue of variations demonstrated by these patterns.

\section{Analysis and discussion}

In the 'love story' genre, the pragmatic meaning of a PE employed in the interaction of characters is modified according to elaboration, extension, combining and questioning patterns applied autonomously or as a complex. The further analysis of these patterns uses schemas that generalize the content and form of a PE. The schemas comprise such notations: 
- N/[NUCLEUS]: the kernel illocutionary meaning of a PE; e.g. [PRAISE]. This notation is placed after the nuclear utterance;

- $\mathbf{S}^{\mathbf{n}}$ [Satelliten]: modification of the nucleus; the attendant ' $n$ ' signifies the medium that instantiates modification - primary $\left(\mathrm{S}^{1}\right)$, secondary $\left(\mathrm{S}^{2}\right)$ or tertiary $\left(\mathrm{S}^{3}\right)$ instantiation; e.g. [Elaboration ${ }^{1}$ ] - primary elaboration instantiated in the character's speech; [Elaboration ${ }^{2}$ ] - secondary elaboration instantiated in the descriptions of non-verbal behavior or/and mental states that accompany the character's speech; [Elaboration ${ }^{3}$ - tertiary elaboration instantiated in the author's comment on the PE.

Elaboration. Typically, elaboration, which specifies the kernel illocutionary meaning of a PE, has the schema $\mathrm{N}+\mathrm{S}^{1}\left(+\mathrm{S}^{1}\right)$, as exemplified in (1), (2), and (3), where the nucleus is followed by one or more primary satellites.

(1) NUCLEUS + Elaboration'. 'You know, one of the hardest things for me, Mel, is knowing that I'll never be both a mother and father to my kids. And they need both, especially Pam.'

'You can't expect that much of yourself [ENCOURAGEMENT]. You're only you. And you give the best you have to give. More than that you can't do. '[Elaboration'] (Steel 1984: 60)

(2) NUCLEUS + Elaboration'. He handed her a tray and prodded her into taking oatmeal, scrambled eggs, bacon, toast, jelly, and a cup of coffee.

'If you think I'm going to eat all that, you're crazy.'

'If you eat even half of it, you'll be in much better shape [ENCOURAGEMENT]. I learnt that as a kid when we lived in Norway. You can't starve yourself in cold weather... or stressed times. Sometimes I went for days without wanting to eat when Dana and I split up, but I forced myself. And I always felt better of it.' [Elaboration'] (Steel 1994a: 101)

(3) NUCLEUS + Elaboration ${ }^{I}+$ Elaboration $^{I} .<\ldots>$ she touched his cheek gently with her fingers, and he looked up at her with a happy look she hadn't seen on a man's face in years, if ever. It made her realize suddenly what she had been missing. 'You're beautiful... [ADMIRATION]. Very, very beautiful... in fact' he beamed [Elaboration']. 'You even look Norwegian.' [Elaboration'] (Steel 1994a: 276)

In the data, there are also cases exhibiting the schemas $\mathrm{N}+\mathrm{S}^{1}\left(+\mathrm{S}^{1}\right)+\mathrm{S}^{2}$, and $\mathrm{N}+\mathrm{S}^{1}\left(+\mathrm{S}^{1}\right)+\mathrm{S}^{3}$ with the secondary and tertiary satellites (Examples 4,5 , 6 and 7).

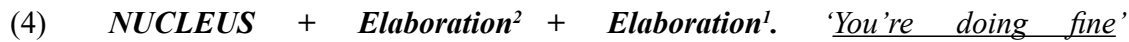
[ENCOURAGEMENT], he said gently [Elaboration'] as he held her. 'You're doing everything you can. The rest is in God's hands' [Elaboration']. (Steel 1994a: 205) 
(5) NUCLEUS + Elaboration ${ }^{2}+$ Elaboration $^{1}+$ Elaboration $^{3}$. It was Christmas eve before she finished some material for him. He read it in one night, and called her in the morning. It was midnight for her, and she was sitting at her desk, working on it, when he called her.

'I love what you did' [PRAISE], he said, sounding jubilant [Elaboration ${ }^{2}$ ]. 'It's absolutely perfect' [Elaboration']. It was even better than he had hoped [Elaboration ${ }^{3}$ ]. (Steel 2008: 487)

(6) NUCLEUS + Elaboration' + Elaboration ${ }^{3}+$ Elaboration $^{3}$. 'You're too big to lose, Joe' [PRAISE], she said honestly. 'I don't think you have any idea how big you are. You're enormous' [Elaboration ${ }^{1}$ ]. He was the biggest man she had ever known [Elaboration ${ }^{3}$. He had an enormous spirit and a brilliant mind [Elaboration ${ }^{3}$. (Steel 2002a: 331)

NUCLEUS + Elaboration ${ }^{1}+$ Elaboration $^{1}+$ Elaboration $^{1}+$ Elaboration $^{3} \cdot{ }^{\prime} Y$ ou are very strong' [ENCOURAGEMENT], she said $\langle\ldots\rangle$ 'and whatever life metes out to you, whatever it is, I want you to remember that you equal to it [Elaboration ${ }^{1}$ ]. God will not give you more than you can handle [Elaboration ${ }^{1}$ ]. And when you think you can bear no more, you must remember that you will survive it. You must know that' [Elaboration ${ }^{1}$ ]. It was a message delivered from the heart [Elaboration ${ }^{3}$ ]. (Steel 1999b: 245)

A secondary satellite featuring the speaker's non-verbal communication may both follow and precede the nucleus, as in (8) rendering the schema $\mathrm{S}^{2}+\mathrm{N}+\mathrm{S}^{2}$.

Elaboration $^{2}+$ NUCLEUS + + Elaboration'. 'Simon ... 'She looked up at him with anguished eyes. 'I'm pregnant.'

He stared at her, and then suddenly he rushed toward her and took her in his arms with a shout of joy [Elaboration ${ }^{2}$ ]. 'Oh darling ... oh darling! ... oh God, I love you!' [LOVE]. When she looked at him again, she saw that he was laughing and crying at the same time [Elaboration ${ }^{2}$ ]. (Steel 1989a: 428)

Modifications of a particular PE in the character's speech are manifested through repetitions (1), (4), (6), synonymous expressions (6), description of details relevant for the nucleus (1), (2), (5), (6), (7), and descriptions of comparison which involves a person (3) or some similar situation (2).

Extension. While exposing the congruent attendant circumstances of a PE, extension, mostly realized through the schema $\mathrm{N}+\mathrm{S}^{1}\left(+\mathrm{S}^{1}\right)$, may highlight the cause (11), consequence (9), (12), evidence (10) or other circumstances, such as condition, motivation, justification, enablement, etc. (see the list of coherence relations in Mann \&Thompson 1988).

(9) NUCLEUS + Extension'. 'Mmmm ... fantastic lunch [PRAISE]. You ladies should open a restaurant. We'd make a fortune for the church '[Extension': consequence]. (Steel 1999b: 159) 
(10) NUCLEUS + Extension'. She is always well when she tends the sick' [PRAISE], her grandmother answered for her. 'It's an odd thing about Alix. She seems to suffer every possible malaise until she is needed by someone sicker, and then she rises to the occasion remarkably' [Extension': evidence]. (Steel 2002a: 334)

(11) NUCLEUS + Extension'. I looked at him across the room, watching him, wondering why I had ever thought I loved him.

'I love being with you. I love having fun with you [LOVE]. You're wild and funny and sweet and entertaining' [Extension ${ }^{1}$ : cause]. (Steel 1999a: 276)

(12) NUCLEUS + Extension ${ }^{1}+$ Extension $^{2}$. What a marvelous cook you are' [PRAISE], Maribelle complimented him. The steaks were good $<\ldots>$. 'Alexis, you really ought to try one of the steaks, they're too good to be true, '[Extension': consequence] she said happily [Extension²: consequence]. (Steel 1989b: 233)

Questioning. This modification pattern introduces an 'incongruent' element into the pragmatic content rendered by a PE. Incongruence between the content of the nucleus and the content of the satellite is either implicit, as in (14), (15) and (16), or made explicit with an adversative conjunction (13). The prevalent modification schema is $\mathrm{N}+\mathrm{S}^{1}\left(+\mathrm{S}^{1}\right)$, as in (13), (14), which may demonstrate an extended stringing of post-positional satellites (15).

(13) NUCLEUS + Questioning . 'You can't change some things, 'she said. $<\ldots>$ 'You didn't give me enough time, 'he said, looking deep into her eyes that were the same color as his own. <...>. 'I was mad. I was scared. I was busy. I hadn't figured it out yet. But I have now,' he said pointedly. <..> 'Look, Kate, I get it. I have a great life. I've built a solid business [SELF-PRAISE], but none of it means as much to me without you' [Questioning ${ }^{1}$. (Steel 2002a: 334)

(14) NUCLEUS + Questioning ${ }^{I}+$ Questioning $^{I}+$ Questioning $^{I}$.'You sound happy, Kate,' Joe said quietly. <...> 'I think I'm happy' [PLEASURE], Kate laughed. 'God knows why. My mother is driving me crazy, she's so lonely, without Clarke [Questioning ${ }^{1}$ ]. Stevie cut most of her hair off last week [Questioning ${ }^{1}$ ]. And Reed knocked out both of his front teeth playing baseball with a friend ' [Questioning ${ }^{1}$ ]. (Steel 2002b: 475)

(15) NUCLEUS + Questioning ${ }^{I}+$ Questioning $^{I}+$ Questioning $^{I}$. 'I'm saying that I love you too much [LOVE] to burden you with an old man. I'm forty-six years old and you're nineteen. That's not fair to you. You deserve somewhat young and alive, [Questioning ${ }^{1}$ ] and after everything settles down here, you'll find someone else to love. $\langle\ldots\rangle$ One day life will be normal again, and you'll meet someone more your age, Zoya [Questioning $\left.{ }^{1}\right]$. $\leq \ldots$. It would be wrong to take you to New York. It would be selfish on my part. I'm thinking of you now, not myself' [Questioning $\left.{ }^{1}\right]$. (Steel 1989a: 241) 
The dataset also contains occasional examples of the schema $\mathrm{S}^{1}+\mathrm{N}+\mathrm{S}^{1}$ demonstrating modification of a PE with pre- and post-positional satellites (16).

(16) Questioning ${ }^{I}+$ NUCLEUS + Questioning ${ }^{I}$. Peter? < ... Peter! You didn't... you couldn't... why would you?' $<$... >

I thought you were in love with Paul when I came back this time. I wanted to know for sure [Questioning ${ }^{1}$. I missed you so much when I was in California... it was all I could think of [LOVE], and then I came back and you looked so sad. $\underline{I}$ thought you were in love with him, and didn't want to see $m e^{\prime}$ [Questioning ${ }^{1}$ ]. (Steel 1999a: 298)

Combining. Combining is adding one PE to another related PE. They may concern one and the same entity (18), or different entities. In the latter case the type of emotion remains the same (17). This modification pattern utilizes the schema $\mathrm{N}+\mathrm{S}^{1}\left(+\mathrm{S}^{1}\right)$ with a post-positional satellite (17), and the schema $\mathrm{S}^{1}\left(+\mathrm{S}^{1}\right)$ $+\mathrm{N}$ with a prepositional satellite (18).

NUCLEUS + Combiningl. 'I love you,' she whispered, and he smiled sleepily in answer.

'I love you too, sweetheart [LOVE-X]. ... I even love your mother' [Combining': LOVE-Y] She giggled and a moment later they were fast asleep. (Steel 2002a: 249)

(18) Combining ${ }^{I}+$ Combining ${ }^{3}+$ NUCLEUS. She wanted to remember what he looked like at this exact moment, to keep her warm in the days to come. $<$... 'Stay safe' [Combining ${ }^{1}$ : WELL-WISHING], she whispered as he pulled her close to him. 'Stay alive' [Combining3: WELL-WISHING] was what she really wanted to say. $<\ldots>$. She didn't want to make this any harder than it was for either of them. 'Ilove you, Joe'. [LOVE] (Steel 2002b: 192)

Complex types. The pragmatic content of a PE may be modified via application of heterogeneous satellites numbering two, as in (19), (20), (21), or more, as in (22), (23) and (24).

NUCLEUS + Extension ${ }^{I}$ Combining C $^{\text {Has anyone told you how terrific you }}$ are, little one?' [PRAISE] < ...> 'You're brave and you're wonderful. You did a beautiful thing for Andrew, and it's going to be good for both of you' [Extension': evidence], and then in a soft voice that took her completely by surprise, 'and I love you for it' ' [Combining': LOVE]. (Steel 2009: 82)

(20) NUCLEUS +Elaboration ${ }^{\text {+ }}$ Extension' 'It'sallright, Joe '[ENCOURAGEMENT], she said quietly [Elaboration ${ }^{1}$ ], sensing his distress over it [pregnancy], and the enormous pressure it added to an already untenable situation. Maybe it was meant to be this way. Maybe it's what I needed to make my decision' [Extension': justification]. (Steel 1999b: 216) 
(21) NUCLEUS + Extension ${ }^{I}+$ Elaboration $^{2}$. She looked up into the brilliant green eyes and shook her head. He put a finger to his lips.

'I know this sounds crazy, Sam, but I love you. I knew it the first time I saw you [LOVE]. I wanted to touch you and to hold you. I wanted to run my hands through that palomino hair' [Extension': consequence]. He smiled gently down at her [Elaboration'], bur Samantha looked pensive. 'Do you believe me, Sam?' (Steel 1989b: 175)

(22) NUCLEUS + Combining ${ }^{I}+$ Questioning $^{I}+$ Elaboration $^{I}$. 'I like her' [LIKING] She said honestly. 'She's a real bright kid [Combining ${ }^{1}$ : PRAISE]. A little screwed up sometimes [Questioning ${ }^{1}$ ], but smart as hell [Elaboration'] ${ }^{1}$. (Steel 1984: 224)

(23) NUCLEUS + Elaboration ${ }^{1}+$ Elaboration $^{2}+$ Questioning $^{2}$. When Bill saw her, he smiled forgetting the pain. 'I'm okey, darling [ENCOURAGEMENT]. Nothing much happened. I got in a fight with a bus moving at high speed. And the bus won. It was a damn thing to do ,'[Elaboration ${ }^{1}$ ], he said with a smile [Elaboration ${ }^{2}$ ], but he looked tired [Questioning ${ }^{2}$ ] (Steel 2001: 178).

NUCLEUS + Elaboration ${ }^{2}+$ Extension $^{1}+$ Combining $^{l}+$ Elaboration $^{3}$. Tanya was back in the same conference room the next morning, and this time Max arrived with his dog, if you could call it that. Harry was closer to the size of a small horse, but he was very well behaved, and sat in the corner, with his gigantic head on his paws. <...> 'He's actually my roommate, not a dog [PRAISE], 'Max said with a grin [Elaboration']. 'He was in a commercial once. I put the money in the stock market, and he's done very well. He pays for his half of the rent [Extension': evidence]. I think of him as more of a son' [Combining ${ }^{1}$ : LOVE]. She could see that he did [Elaboration $\left.{ }^{3}\right]$. (Steel 2008: 190)

Though complex types mostly adopt the schema $\mathrm{N}+\mathrm{S}^{1}\left(+\mathrm{S}^{1}\right)$ with postpositional satellites (see the examples above), the schema $\mathrm{S}^{1}\left(+\mathrm{S}^{1}\right)+\mathrm{N}$ with the satellites in the initial position (Examples 25, 26 and 27) is also rather common.

(25) Combining ${ }^{I}+$ NUCLEUS + Elaboration $^{1}$. Caroline $<\ldots>$ handed her the hot chocolate. 'I'm glad that you called me [Combining': PLEASURE]. I've always loved you ...' [LOVE] She hesitated for a moment, glancing into the fire, and then back at Sam. 'Just as much as I loved Barb' [Elaboration']'. (Steel 1989b: 49-50)

(26) Combining ${ }^{I}+$ NUCLEUS + Elaboration ${ }^{1}$. It [the party] is pretty' [Combining ${ }^{1}$ : LIKING-Y], he said, as she noticed the color of his eyes. They were the same as hers. 'And so are you' [LIKING-X], he said unexpectedly. $<\ldots>$ 'You're anything but boring [Extension ${ }^{1}$ : motivation]. I just thought you might like to dance with me.' (Steel 2002a: 34) 
Extension $^{I}+$ Extension $^{2}+$ NUCLEUS + Extension $^{I}+$ Questioning $^{I}+$ Extension'. 'You can't go away. ' $<$... > I have to. I can't stay here, close to you like this. It's driving me crazy ... Oh, Gabbie ...' [Extension': consequence] The words were lost as he pulled her close to him and she buried her face in his powerful chest, his arms held tightly around her [Extension': consequence]. 'I love you so $\underline{\text { much }}[\mathrm{LOVE}] . .$. I want to be with you all the time ... I want to talk to you ... hold you ... take care of you ... I want to be with you forever [Extension ${ }^{1}$ : consequence] ... but how can we do this? I've been going crazy for the past four days, 'he said, sounding agonized [Questioning ${ }^{1}$ ] as she looked up at him in wonder, and all he wanted to do was to keep her in his arms for the rest of time [Extension?: consequence]. (Steel 1999b: 184)

Along with the primary media of portraying a PE, the author uses the secondary media which, similarly to the primary ones, are placed either after the nucleus (Examples 21, 23 and 24) or before it (Example 27). The interplay of primary and secondary media that respectively represent the character's speech, and the character's non-verbal behavior or explicit mental states, contributes to featuring a PE as a multidimensional discourse phenomenon the description of which makes the text evolve.

Analysis of the data sets off the major issues to be discussed. First, these are frequencies of modification types tracked in the novels by Danielle Steel. Second, these are factors that influence variability within autonomous and complex types.

The frequencies of modification types registered in the analyzed novels are demonstrated in Table 1.

\begin{tabular}{|l|l|c|c|}
\hline \multicolumn{1}{|c|}{$\begin{array}{c}\text { Modification } \\
\text { patterns }\end{array}$} & \multicolumn{1}{|c|}{ Kind of change } & $\begin{array}{c}\text { Number } \\
\text { of examples }\end{array}$ & $\%$ \\
\hline Extension & Exposure of the congruent context of a PE & 757 & 33.1 \\
\hline Combining & Adding another PE & 610 & 26.7 \\
\hline Questioning & Exposure of the incongruent context of a PE & 428 & 18.7 \\
\hline Elaboration & Specification of a PE & 302 & 13.2 \\
\hline Complex types & Combination of the above modifications & 189 & 8.3 \\
\hline TOTAL & & 2,286 & 100 \\
\hline
\end{tabular}

Table 1. Modifications of positive expressives in the current discourse space depicted in the literary text 
As Table 1 shows, nearly one third of the dataset is comprised by the examples of extensions that feature the semantically congruent 'frame' of a PE. Over a quarter of the examples demonstrate combining one PE with another PE, which in the literary text contributes to moving the plot forward. The examples with questioning $(18.7 \%)$ roughly point to the portion of 'collisions', mostly associated with the 'love story' genre. A comparatively low number (13.2\%) of examples with elaboration that specifies a PE may be explained by the text's written form with its tendency to avoid redundancy in a narrow context. (Presumably, elaboration in a narrow context is more typical of everyday oral speech). The lowest number of samples with complex types (8.3\%) may be also accounted for by avoiding redundancy, but in a wider context. At the same time, frequencies in application of the considered devices may also depend on the author's narrative technique.

According to the analysis, within an autonomous modification pattern, variations are caused by (a) different numbers of homogeneous satellites attached to the nucleus. These numbers are in the range of 1-4, with the tendency to their increase within the elaboration and questioning types. Another factor is (b) the interplay of primary, secondary and tertiary media that instantiate modifications of a PE through the character's or the author's speech. Secondary and tertiary instantiations are not typical of the extension pattern that adds a new congruent detail to the context where a PE is profiled. Adding such a detail rarely associates with exposure of the speaker's non-verbal behavior and mental states, and it is rarely commented on by the author. One more factor is (c) options in the lineal arrangement of the text that describes a PE. Here, the satellite may either precede or/and follow the nucleus. In the majority of cases, the satellite is post-positional. Pre-position of the satellites that occurs in all modification patterns is less frequent. Within complex modification patterns, variations depend on the same three factors, with the only difference in the nature of satellites: they are heterogeneous, and therefore the increase of their number and their variable stringing in a complex pattern implies a potentially infinite diversity of such patterns.

\section{Conclusion}

Linguistic classification of expressive speech acts, designed with regard to the latter's cognitive (semantic), communicative and semiotic properties, includes conventional and conversational expressives that communicate the speaker's emotions. Conventional expressives, or behavitives, are listener-centered; conversational expressives, or emotives, are both speaker- and listener-centered, being also positive, negative, bi-polar, and ambivalent. This study focused on 
emotives whose pragmatic (illocutionary) meaning gets modified in discourse as communication mediated by speech.

In the current discourse space speech integrates with extralinguistic factors. Therefore, an emotive speech act is instantiated not only in the speech proper (primary instantiation), but also in that which attends it - different kinds of non-verbal communication and the speaker's explicit mental states (secondary instantiation), as well as the speaker's covert mental states to which an 'observer' has a virtual access. These instantiations of an emotive speech act are tractable in the literary text, which makes it an appropriate source of data for the analysis of modifications exhibited by an emotive speech act in the current discourse space.

This study hypothesized that modifications of an emotive speech act instantiated through different discourse media have regular patterns associated with the cognitive operations of elaboration, extension, questioning and combining. Elaboration specifies the pragmatic meaning of an emotive. In extension, this meaning is supplied with contiguous congruent details. In questioning such details are incongruent. Combining links one emotive with another homogeneous emotive. Our hypothesis was tested via analysis of the congeneric group of positive emotives as they are portrayed in the literary text.

The analysis of linguistic data confirmed existence of elaboration, extension, questioning and combining as modification patterns exhibited by positive emotions in the current discourse space. Combination of such patterns creates complex types. Semantic modifications of positive emotives are implemented through primary, secondary, and tertiary discourse instantiations. Besides, the analysis, undertaken in terms of hypotactic relations, where the kernel pragmatic meaning was considered as the nucleus, and the modification of this meaning was interpreted as the satellite, exposed variability within autonomous and complex modification patterns. In autonomous patterns, variations depend on the number of homogeneous satellites attached to the nucleus, the kinds of their instantiations, and the sequential order of the nucleus and its satellites. Sequential organization is an inherent formal property of speech, but the order of speech constituents, including the order of the nucleus and its satellites in a speech act, depends on the speaker, and - in the literary text - the author of this text. Variability of complex patterns increases due to multiple options of combing heterogeneous satellites modifying the same nucleus. In general, variability of patterns that mold discourse modifications of positive expressives is practically infinite, but the media that provides this variability is finite, and their diverse combinability is a matter of the writer's choices and creativity.

The analysis of positive emotives portrayed in the literary text of a particular author demonstrated a high probability of the relation between the text's genre 
and prevalence of particular patterns that feature modification of positive emotions in the current discourse space. The studied literary texts that belong to the 'love story' genre demonstrated prevalence of extension and combining patterns. Meanwhile, preference given to particular modification patterns of emotives may be a particular characteristic of the writer's narrative technique.

It can be argued that the properties exhibited by the analyzed positive emotives may be extended to the other types of emotive speech acts - negative, bipolar, and ambivalent. In this case, the conclusive remark concerns all emotives as a pragmatic class. The latter has its own pragmatic meaning stratified into types and sub-types. In discourse, this meaning gets modified in accordance with regular patterns that have a high degree of their internal variability.

Modification of speech acts in the current discourse space constitutes an important agenda for the theory of speech acts, semantics of illocution in particular, for text linguistics, and for discourse studies. Together, these fields may provide an interdisciplinary framework within which the considered problem may obtain a more detailed and precise discussion.

\section{References}

Alekseev, A. and Shipilova, D. (2018) 'The role of expressive speech acts in the political image construction.' Current Issues in Philology and Pedagogical Linguistics 2(30), 7-15.

Aristidou, A., Charalambous, P. and Chrysanthou, Y. (2015) 'Emotion analysis and classification: Understanding the performers' emotions using the LMA entities.' Computer Graphics Forum 34(6), 262-276.

Arutyunova, N. D. (1990) 'Diskurs.' [Discourse]. In: Yartseva, V. N. (ed.) Lingvisticheskij Ehnciklopedicheskij Slovar. Moskva: Sovetskaya Ehntsiklopediya. 136-137.

Austin, J. L. (1962) How to Do Things with Words. London: Oxford University Press.

Carretero, M., Maíz-Arévalo, C. and Martínez, M. Á. (2015) 'An analysis of expressive speech acts in online task-oriented interaction by university students.' ProcediaSocial and Behavioral Sciences 173, 186-190.

Damasio, A. (1999) The Feeling of What Happens: Body and Emotion in the Making of Consciousness. San Diego, New York and London: Harvest Book.

Dirven, R. and Verspoor, M. (eds) (2004) Cognitive Exploration of Language and Linguistics. $2^{\text {nd }}$ ed. Amsterdam and Philadelphia: John Benjamins.

Fauconnier, G. and Turner, M. (2002) The Way We Think: Conceptual Blending and the Mind's Hidden Complexities. New York: Basic Books.

Guiraud, N., Longin, D., Lorini, E., Pesty, S. and Rivière, J. (2011) 'The face of emotions: A logical formalization of expressive speech acts.' In: Tumer, K. P., Yolum, L., Sonenberg, L. and Stone, P. (eds) Proceedings of the 10th International Conference on Autonomous Agents and Multiagent Systems, 3. Richland, SC: International Foundation for Autonomous Agents and Multiagent Systems. 1031-1038.

Izard, C. E. (1977) Human Emotions. New York: Plenum.

Izard, C. E. (1991) The Psychology of Emotions. New York: Plenum. 
Kisil, A. K. (2018) Situativnaya Variativnost Sredstv Vyrazheniya Emotsii v Sovremennom Angliiskom Yazyke. Dissertatsiya kandidata filologicheskikh nauk. Rukopis. [Situational Variation of the Means for Manifestation of Emotions in Modern English. Manuscript. Ph.D. Dissertation in Philology]. Rostov-na-Donu: Yuzhnyi Federalnyi Universitet.

Lakoff, G. and Turner, M. (1989) More Than Cool Reason. A Field Guide to Poetic Metaphor. Chicago and London: The University of Chicago Press.

Lalu, B. S. and Yuyun, Y. (2017) 'An analysis of expressive speech acts use by Steve Rogers as the main character in civil war movie.' Journal of English Language and Language Teaching (JELLT) 1(2), 61-67.

Lindquist, K. A. (2013) 'Emotions emerge from more basic psychological ingredients: A modern psychological constructionist model.' Emotion Review 5(4), 356-368.

Langacker, R. W. (2008) Cognitive Grammar: A Basic Introduction. Oxford: Oxford University Press.

Lewandowska-Tomaszczyk, B. and Wilson, P. A. (2014) 'Self-conscious emotions in collectivistic and individualistic cultures: A contrastive linguistic perspective.' In: Romero-Trillo, J. (ed.) Yearbook of Corpus Linguistics and Pragmatics. Vienna: Springer International Publishing. 123-148.

Lewis, M., Haviland-Jones, J. M. and Berrett, L. F. (eds) (2008) Handbook of Emotions. New York and Nomdon: Guilford Press.

Lomas, T. (2017) 'The value of ambivalent emotions: A cross-cultural lexical analysis.' Qualitative Research in Psychology. Online document. Retrieved on 23 June 2019 from https://www.tandfonline.com/doi/abs/10.1080/14780887.2017.1400143?journa 1Code=uqrp20.

Maíz-Arévalo, C. (2017) 'Expressive speech acts in educational e-chats.' Pragmática Sociocultural 5(2), 151-178.

Mann, W. C. and Thompson, S. A. (1988) 'Rhetorical structure theory: Towards a functional theory of text organization.' Text 8, 243-281.

Norrick, N. R. (1978) 'Expressive illocutionary acts.' Journal of Pragmatics 2(3), 277-291.

Orlova, N. N. (2008) Yazykovye Sredstva Vyrazheniya Emotsii: Sintaksicheskii Aspekt (na Materiale Sovremennoi Angliiskoi Prozy). Dissertatsiya kandidata filologicheskikh nauk. Rukopis. [Linguistic Means for Manifestation of Emotions: A Syntactic Aspect (the Data of Contemporary English Prose). Manuscript. Ph.D. Dissertation in Philology]. Rostov-na-Donu: Yuzhnyi Federalnyi Universitet.

Ortony, A. and Turner, T. J. (1990) 'What's basic about basic emotions?' Psychological Review 97(3), 315-331.

Oventile, R. S. (2005) 'Speech acts.' In: Stranzy, P. (ed.) Encyclopedia of Linguistics. New York, Oxon: Fitzroy Dearborn, Vol. 2. 1016-1018.

Ronan, P. (2015) 'Categorizing expressive speech acts in the pragmatically annotated SPICE Ireland corpus.' ICAME Journal 39, 25-45.

Searle, J. R. (1969) Speech Acts: An Essay in the Philosophy of Language. Cambridge: Cambridge University Press.

Slyvka, N. P. (2012) Dyskursyvna Polivektornist Pozytyvnoho Ekspresyvu (na Materiali Suchasnykh Anhlomovnykh Tekstiv Zhinochykh Romaniv). Rukopys. Dysertatsiia kandydata filolohichnykh nauk. [Discourse Polyvector Nature of the Positive Expressive (the Data of Contemporary English Female Novels). Manuscript. Ph.D. dissertation in philology]. Cherkasy: Cherkaskyi Natsionalnyi Universytet Imeni Bohdana Khmel'nytskoho. 
Thamm, R. A. (2006) 'The classification of emotions.' In: Stets, J. E. and Turner, J. H. (eds) Handbook of the Sociology of Emotions. Boston, MA: Springer. 11-37.

van Dijk, T. A. (ed.) (1976) Pragmatics of Language and Literature. Amsterdam and New York: North-Holland.

van Dijk, T. A. (1981) Studies in the Pragmatics of Discourse. The Hague: Mouton.

Velivchenko, V. O. (2011) Implikatura Yak Sposib Transliatsii Emotsii Movtsia (na Materiali Suchasnoho Anhlomovnoho Emotyvnoho Dyskursu). Rukopys. Dysertatsiia kandydata filolohichnykh nauk. [Implicature as a Means of Communicating the Speaker's Emotions (the Data of Contemporary English Discourse). Manuscript. Ph.D. dissertation in philology]. Cherkasy: Cherkaskyi Natsionalnyi Universytet Imeni Bohdana Khmelnytskoho.

Vernant, D. (2008) 'The classification of speech acts revisited: A dialogical and actional perspective.' Online document. Retrieved on 22 June 2019 from https:// pdfs.semanticscholar.org/0953/254f2fcc35fc5c67034f18239747291fe653.pdf? $\mathrm{ga}=2.125646666 .1758449119 .1561217148-946040177.1561217148$.

Weigand, E. (2010) Dialogue: The Mixed Game. Amsterdam and Philadelpia: John Benjamins.

Wierzbicka, A. (1997) Emotions Across Languages and Cultures: Diversity and Universals. Cambridge: Cambridge University Press.

Zhabotynska, S. A. (2018) 'Semantyka illokutsii: linhvokohnityvnyi rakurs (na materiali anhlomovnoho movlennievoho aktu dokoru).' [Semantics of illocution: A cognitive linguistic perspective (the English speech act of reproach)]. Visnyk Lvivskoho Univnrsytetu. Seriia Filolohichna 70, 185-203.

Zachar, P. (2006) 'The classification of emotion and scientific realism.' Journal of Theoretical and Philosophical Psychology 26, 120-138.

\section{Sources}

Steel, D. (1983) Summe's End. New York: A Dell Book.

Steel, D. (1984) Changes. New York: A Dell Book.

Steel, D. (1989a) Zoya. New York: A Dell Book.

Steel, D. (1989b) Palomino. New York: A Dell Book.

Steel, D. (1994a) Accident. New York: Delacorte Press.

Steel, D. (1994b) Vanished. New York: A Dell Book.

Steel, D. (1996) Lightning. London: Corgi Books.

Steel, D. (1999a) The Klone and I. London: Corgi Books.

Steel, D. (1999b) The Long Road Home. New York: A Dell Book.

Steel, D. (2001) The Kiss. London: Corgi Books.

Steel, D. (2002a) Lone Eagle. London: Corgi Books.

Steel, D. (2002b) Mirror Image. London: Corgi Books.

Steel, D. (2008) Bungalow 2. London: Corgi Books.

Steel, D. (2009) Once in a Lifetime. London: Little, Brown Book Group.

Svitlana Zhabotynska, Doctor of Linguistics, Professor, Department of English Philology and Methods of Teaching English, Bohdan Khmelnitsky National University of Cherkasy. Author of over 170 publications in the fields of cognitive linguistics, political linguistics, and linguistic pragmatics. Twice 
Fulbright Scholar. First Vice-President of the Ukrainian Association of Cognitive Linguistics and Poetics. At her home university she teaches general linguistics, cognitive linguistics (theoretical and applied aspects), semantics, and conceptual modeling of information. She has been guest-lecturing at many universities in Ukraine and abroad. As a researcher of international scholarly projects (2015-2017), she studied perception of the EU by Ukraine, and the neurocognive foundations of Ukrainians' bilingualism. ORCID: 0000-0001-9841-6335

Address: Svitlana Zhabotynska, Institute of Foreign Languages, Bohdan Khmelnitsky National University of Cherkasy, 81 Shevchenko Blvd., Cherkasy 18031, Ukraine. [e-mail: saz9@ukr.net]

Nataliia Slyvka, Ph.D. in Linguistics, Associate Professor, Department of English Philology and Methods of Teaching English, Bohdan Khmelnitsky National University of Cherkasy. Author of 15 publications in the field of linguistic pragmatics. Participant of international linguistic conferences held in Ukraine and abroad. At her home university, she teaches theoretical phonetics and practical English. She is a member of International Phonetic Association, and a participant of international phonetic workshops. At present, the fields of her research interests are text theory and discourse analysis viewed from a cognitive perspective. ORCID: 0000-0001-5191-349X

Address: Nataliia Slyvka, Institute of Foreign Languages, Bohdan Khmelnitsky National University of Cherkasy, 81 Shevchenko Blvd., Cherkasy 18031, Ukraine. [e-mail: nataliya.slyvka@gmail.com] 